\title{
Dendroclimatological potential of the Australian red cedar
}

\author{
I. Heinrich ${ }^{\mathrm{A}, \mathrm{B}, \mathrm{C}}$ and J. C. G. Banks ${ }^{\mathrm{A}}$

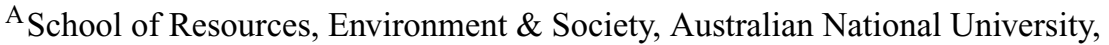 \\ Canberra, ACT 0200, Australia. \\ BPresent address: Department of Geosciences, Geography, University of Fribourg, \\ 1700 Fribourg, Switzerland. \\ ${ }^{\mathrm{C}}$ Corresponding author. Email: ingo.heinrich@unifr.ch
}

\begin{abstract}
We examined Toona ciliata M.Roemer (Australian red cedar) for its potential to deliver annually resolved tree-ring proxy data. Such proxies are valuable and sought-after sources for reconstructing climate beyond instrumental records, especially in Australia. T. ciliata was chosen because it is one of the few deciduous tree species in Australia experiencing a seasonally dormant period of the cambium. This was confirmed by a preliminary treering analysis which revealed distinct growth rings. Because of initial uncertainties regarding reliable annual growth rings in the wood of T. ciliata, a dendrometer-band study was conducted in addition to the tree-ring analysis. Stem increments revealed a common period of dormancy during winter and the measurements were found to correlate with both precipitation and temperature, depending on the site. For the first time, our tree-ring analysis demonstrated that samples from different individuals can be cross-dated and the resulting site index from Upper Kangaroo Valley (New South Wales) has the potential to reconstruct early season temperatures and late-season rainfall.
\end{abstract}

\section{Introduction}

Tree-ring chronologies have been used to reconstruct the variability of past climate in many regions of the world, particularly in North America and Europe. Dendrochronology, or tree-ring dating, has in general not been widely applied in tropical forests and even less so in the Australian tropics because of the extreme rarity of species producing anatomically distinct annual growth rings. The vast Australian inland area of this second-driest continent does not receive sufficient rainfall to support tree growth. Only near the coast and its hinterland, trees flourish but decrease in size along a rainfall gradient into the inland area where eucalypts and acacias comprise the majority of the phanerophytic vegetation. Unfortunately, most species of the two genera and of many other Australian genera are well adapted to the Australian climate and exhibit rather strong opportunistic growth, with non-annual growth zones that are less suitable for dendrochronology. Only under exceptional circumstances, i.e. when trees grow in mountain regions (Banks 1982) or in strongly monsoonal climate (Mucha 1979), has the development of annual tree-ring chronologies been achieved. In contrast, Tasmanian projects have resulted in chronologies spanning over many centuries, reconstructing climate in the south-eastern region of Australia (e.g. Cook et al. 1991, 1992; Allen et al. 2001; Allen 2002). In mainland
Australia, dendroclimatological studies (e.g. Ash 1983; Rayner 1992) have been conducted, with preliminary results indicating that some Australian tree species are suitable for reconstructing climate patterns. On the other hand, in neighbouring countries it has been demonstrated that dendroclimatological studies can be successful (Berlage 1931; Jacoby and D’Arrigo 1990; Murphy 1994; Buckley etal. 1995; Stahle etal. 1998). Sources for terrestrial proxy data in Australia are rare and only in the semi-arid to humid zones can sources such as lake sediments or archives of vegetation change (Stocker 1971; Kershaw 1978; Hopkins et al. 1990, Hopkins et al. 1996; D'Costa and Kershaw 1995; De Deckker 2001; Bowler et al. 2003), and tree-rings (Ogden 1981; Schweingruber 1992) be expected. The inland zone is too dry to conserve any natural archives and adjacent savanna and dry eucalypt-forest communities are prone to regular fires, and consequently cannot hold any long-term records (Bowman and Cook 2002). Additionally, trees do not have the chance to grow to old trees because of the damage by insects such as termites (Mucha 1979). Thus, no long-term, annually resolved climate proxy tree-ring record exists yet for mainland Australia.

Therefore, the objective was to show that Toona ciliata M.Roemer (Meliaceae) holds the potential to build proxydata chronologies that can be used for climate reconstructions 
along the east coast of Australia, reaching into the preinstrumental periods.

The Australian red cedar belongs to the Meliaceae family, which is commonly known as the mahogany family and is part of the Indo-Malayan floristic element. The genus Toona is closely related to Cedrela, the neotropical counterpart with which it has been repeatedly united and separated (Boland et al. 2002). Edmonds (1995) reported a phenomenal range of morphological variation, even within and among trees in the same population. Many of the characteristics used by earlier workers (e.g. Bahadur 1988) to distinguish the species have been demonstrated by Edmonds (1995) to be only minor morphological variations. Therefore, in the most recent revision of the genus she suggests that Toona consists of only four, or possibly five, species (Edmonds 1995). T. ciliata is a tall deciduous, often buttressed, tree usually up to about $40 \mathrm{~m}$ in height and with stem diameter of up to $1-3 \mathrm{~m}$. The bark and wood of T. ciliata have a strong odour of cedar when initially cut; hence, the common name Australian red cedar. This name is also explained by the colour of the inner bark and the usually light to dark red wood (Floyd 1979; Boland et al. 2002). The new foliage appearing after the dormant period is bright pink at first, then develops into a more bronze colour and turns light green, before finally displaying the fresh green of the adult leaves. The fact that $T$. ciliata is leafless during the dry season, followed by a period of a few weeks with very distinct red leaves, made it easy for timber cutters to identify the valuable Australian red cedar trees, which partly explains the rapid loss of large forest stands in eastern Australia (Vader 1987). The Australian red cedar was formerly most plentiful on the basalt-derived alluvial flats of the larger rivers along the east coast of Australia. The species still occurs in the remnants of warm temperate, subtropical and tropical rainforests between sea level and $1500 \mathrm{~m}$ above sea level, where it grows in both primary and secondary rainforests. In Australia, T. ciliata grows best on rich alluvial or volcanic soils with a neutral to acid $\mathrm{pH}$ range in wind-sheltered positions and is also common on krasnozems derived from basalt. It can tolerate a few frosts each year and prefers a mean annual rainfall of $1200-3800 \mathrm{~mm}$.

The Australian red cedar is the most wide-ranging Toona species (Edmonds 1995), extending naturally from eastern Pakistan and India through to South-east Asia and southern China, and from Hainan Island to the Philippines and eastern Australia. In Australia, the species occurs from Cape York to just south of Sydney (Boland 2000). In other countries of its distribution, e.g. India, where the species grows in the tropical parts of the sub-Himalayan tract and also in the Western Ghats often in wet evergreen forests and scattered in moist deciduous forests, the annual rainfall ranges from 1100 to $4000 \mathrm{~mm}$ per year and temperatures from 0 to $35^{\circ} \mathrm{C}$ and the species will tolerate some frosts but is sensitive to drought. In the western sub-Himalayan tract, $T$. ciliata is found chiefly at moist sites, along rivers and gullies and even in swamp forests (Boland 2000). Throughout its natural range, $T$. ciliata, like all Toona representatives, is susceptible to attacks by the shoot borer Hypsipyla robusta Moore. The larvae bore into the new shoots and excavate a hollow, causing the growing tip above to die. The attack on young trees can destroy the form, suppress growth and even kill them, with negative effects on the tree-ring analysis. It has been observed that especially young trees growing in light conditions or even open-grown trees usually have a significantly higher borer infestation than do mature trees in closed-forest habitats. It is probable that at least several generations of the insects would occur each year but long-term fluctuations of its populations have not been reported so far (Mo et al. 1997a, 1997b).

This study consists of two parts: (1) monitoring tree growth during one growing season by means of dendrometer bands and (2) an examination of tree rings by using treecore samples. The study concentrates on the Australian red cedar because it is one of the few deciduous tree species in Australia experiencing a dormant period of the cambium, a general indicator that missing rings might not be a problem as in many other non-deciduous tropical tree species. In addition, it has a wide latitudinal range, occurring from Cape York to just south of Sydney, which enables the application of a sample strategy adjusted for the tropics, whereby starting in higher latitudes and, with more knowledge gained, approaching the lower latitudes (Stahle 1999).

\section{Materials and methods}

\section{Dendrometer bands}

Dendrometer bands have often been used to detect the seasonal growth patterns of trees because they offer an easy way for measuring changes in the diameters of tree trunks (Bormann and Kozlowski 1962). Simple manual dendrometer bands are sufficient in measuring the seasonal variation of tree-trunk increments. Dial gauge dendrometers operate with high mechanical precision but because of their special design they measure diameter-growth increments only along one radius, and hence, their precision is confined to one radius of the stem. Only if a study aims to reveal differences of various radii of one tree trunk, is the usage of dial gauge dendrometers justified. Simple dendrometer bands possess adequate precision for seasonal-growth studies and have the advantage of recording average circumferential increase, which can be converted to average radial increase for the entire bole section (Bormann and Kozlowski 1962).

Tree trunks usually experience a small amount of shrinkage in the afternoon because of stem dehydration caused by excess of transpiration over water absorption. During the night the process is reversed, i.e the reduction in the rate of water loss or the increase in the rate of water gain causes cell volumes to increase, and tree stems distend again (Kozlowski 1962). Therefore, the manual recordings should, if possible, always be conducted during the same time of the day. Because of their sufficient accuracy and low-budget construction costs, dendrometer bands were used in the current study. 


\section{Study sites}

Two trees were banded and monitored at the Australian National Botanic Garden (ANBG) in Canberra $\left(35^{\circ} 17^{\prime} \mathrm{S}, 149^{\circ} 07^{\prime} \mathrm{E}, 585 \mathrm{~m}\right.$ a.s.1.) and three trees each on private properties in Robertson $\left(34^{\circ} 35^{\prime} \mathrm{S}, 150^{\circ} 35^{\prime} \mathrm{E}\right.$, $750 \mathrm{~m}$ a.s.1.) and Upper Kangaroo Valley (UKV) $\left(34^{\circ} 65^{\prime} \mathrm{S}, 150^{\circ} 63^{\prime} \mathrm{E}\right.$, $310 \mathrm{~m}$ a.s.1.), New South Wales, during the growing period 2001-2002. In the ANBG, the specimens are approximately 20 years old and grow in a rainforest-gully set up artificially. In Robertson, the trees are part of a mixed-species reforestation scheme conducted on a private property, whereas in UKV the site is located on a former dairy farm, with large patches of rainforest regenerating after the last clearing activities in the early 1900s. The ANBG site is located outside of the species' natural distribution because winter temperatures (long-term annual average for the lowest minimum temperature is $-10^{\circ} \mathrm{C}$ ) and annual amounts of precipitation (long-term mean $625.5 \mathrm{~mm}$ ) are too low. In Robertson, higher amounts of annual rainfall (long-term mean $1650 \mathrm{~mm}$ ) and occasional frosts (long-term annual average for the lowest minimum temperature is $-6^{\circ} \mathrm{C}$ ) are experienced. Therefore, Robertson can be regarded to be near the limit of the natural distribution of the species. The third site, UKV, is surrounded by steep sandstone cliffs marking the edge of the Illawarra escarpment, with the next village Robertson on top of the tablelands only $10 \mathrm{~km}$ away. Long-term precipitation averages for UKV show evenly distributed monthly amounts, with an annual average of $1439.2 \mathrm{~mm}$ and a mean annual temperature of $15.5^{\circ} \mathrm{C}$ (Fig. 1). The minimum temperatures rarely drop below $0^{\circ} \mathrm{C}$, and the site is located within the natural range of the Australian red cedar. The climate is still subtropical, owing to the maritime influence and the evenly distributed rainfall. The averages are somewhat misleading, since during drought periods the amounts of rain can be much smaller for months.

The increment data measured with dendrometer bands at the three sites are compared with temperature and rainfall data that have been averaged and summed, respectively, corresponding with the number of days of each measurement interval.

\section{Dendroclimatology}

The dendrochronological methods applied in the current study follow the general routines described in Stokes and Smiley (1968); Fritts (1976); Schweingruber (1983) and Cook and Kairiukstis (1990). The sample strategy recommended by Schweingruber et al. (1990) and Worbes (1990) for tropical to subtropical trees was applied at UKV in south-eastern New South Wales, where 17 core samples were collected from 12 subdominant trees growing in patches of regenerating forests on the same farm the dendrometer study was conducted. In

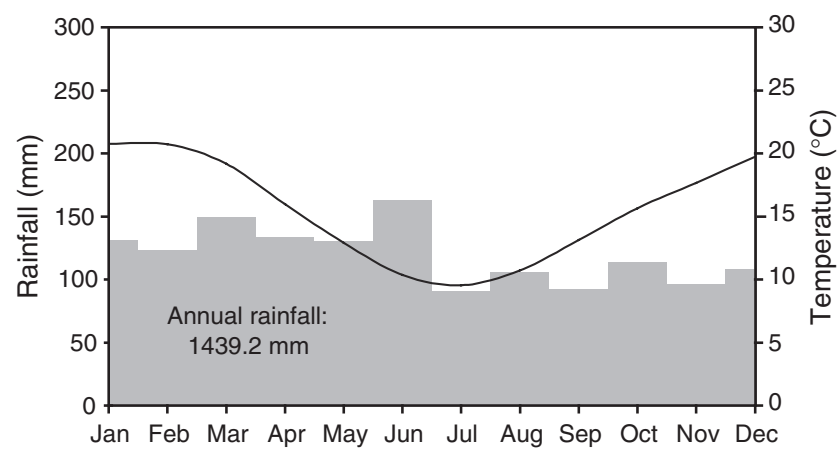

Fig. 1. Rainfall (bars) and temperature (line) derived from long-term average ( 84 years) for Kangaroo Valley (Source: Bureau of Meteorology, Canberra 2002). addition, one sample was collected from a large paddock tree. The number of specimens was restricted because the site is located on private land. All trees sampled were at least $100 \mathrm{~m}$ away from the Kangaroo River and grew on slope angles between $3^{\circ}$ and $20^{\circ}$, with well drained rich alluvial soils. One tree was sampled repeatedly during one season to monitor different stages of intraseasonal growth and to verify results of earlier studies conducted in India. Chowdhury (1940) and Bhattacharyya et al. (1992) found that T. ciliata exhibited distinct growth rings, initial parenchyma and earlywood vessels.

The surfaces of the core samples were smoothed according to routine sample preparations with a belt-sander using paper-grit size of 240 (Bowers 1964), followed by an orbital sander treatment with paper of increasingly fine grit size up to 1200 (Pilcher 1990). The smooth surface of the cores allowed them to be scanned in highresolution mode and imported to the WinDENDRO program for further analysis (WinDENDRO 2003). Individual samples were checked in advance under low magnification for problematic zones such as narrow or false rings, and some were removed before continuing with the analysis. Initial cross-dating was achieved visually and graphically in WinDENDRO and the final quality control was aided by COFECHA software (Holmes 1994).

As an indicator for the correlation between the trees of each site, the mean interseries correlation was used to quantify within-site commonalities. The mean sensitivity is a measure of relative difference in width from one ring to the next. It indicates whether the samples are sensitive or complacent, and thus, more or less suitable for dendroclimatology. A complacent ring-width series has a small variability, which theoretically suggests that growth is relatively unaffected by variations of ecological factors such as climate. In contrast, a sensitive tree-ring series is usually affected by such factors and exhibits high-frequency variance (Kaennel and Schweingruber 1995). The mean sensitivity is a statistical parameter mainly suited for analysis of the high-frequency variance. Moreover, it provides only one average value for the entire segment length. Alternatively, the standard deviation is a good quantifier of the variance in all frequency domains. The coefficient of variation, derived from the standard deviation, is independent of the level of growth, which makes direct comparisons before and after the standardisation procedure, as well as among trees, possible (Fritts 1976). The mean first-lag autocorrelation is a measure of association between the series lagged in time. A comparison of the autocorrelation computed before and after the standardisation helps to control the quality of the detrending technique applied (Cook and Kairiukstis 1990).

Absolute measures of the chronology's quality, such as Pearson's correlation coefficient, often do not represent the most confident estimate of the chronology with decreasing sample numbers. This problem occurs when the later part of the series is used to reconstruct a climate parameter for which a regression analysis indicated a good fit with data from the earlier part of the series. Usually, with decreasing sample size the chronology error increases because the uncommon variance cancels out less and less, affecting the accuracy of the climate reconstruction process (Briffa and Jones 1990). To counteract this problem the computer program ARSTAN (Cook and Holmes 1986) facilitates an estimation of the series reliability by computing the running expressed population signal (EPS) (Wigley et al. 1984; Briffa and Jones 1990), which is a guide to assess the likely loss of reconstruction accuracy. Wigley et al. (1984) gave EPS $=0.85$ as a reasonable limit for the chronology based on a finite number of trees, to still be a reliable approximation of the theoretical population chronology from which it is assumed to have been drawn.

After the quality of the cross-dating has been verified it can be exposed to various techniques, filtering out unwanted and enhancing 
the desired signal. One source of systematic mistakes is the positive relationship between the raw ring width and the year-to-year spread in variance. The juvenile period of a tree is usually characterised by large increments and large local variance, which both decrease with increasing age to a level typical for each species. This growth tendency in each tree series, if not treated, would import unwanted trends into dendroclimatological studies (Fritts 1976). Therefore, the variance was stabilised by a power transformation. The overall age trend was removed by means of a 30 -year cubic smoothing spline function with a $50 \%$ cutoff, i.e. $50 \%$ of the variance in each series at the period of 30 years was removed (Cook and Peters 1981). The resulting tree-ring indices were exposed to a simple correlation analysis, with Pearson's coefficient computed for monthly climate data and annual tree rings to identify important forcing factors controlling tree growth. The monthly climate data available comprise precipitation, maximum, minimum and mean temperatures, relative humidity and the number of clear and cloudy days.

\section{Results}

\section{Dendrometer bands}

The diameter increments of Trees 1 and 2 in the ANBG are presented in Fig. 2. The measurements cover the whole vegetation period 2001-2002 and the beginning of the period 2002-2003. After the dormant period in winter 2001, the trees became measurably active at the beginning of November 2001 and from the end of October to the beginning of November 2002. Approximately $85 \%$ of the diameter increment occurred between mid-December 2001 and midApril 2002, and from the beginning of December 2002 to the end of the experiment in mid-January 2003. The dormant period lasted from the end of May to mid-October 2002 (Fig. 2).

Canberra rainfall and temperature records are used to examine the effects of the weather patterns on tree growth. The summers in Canberra are usually hot and dry, with occasional cold fronts bringing a cool change and some rain. These fluctuations are also visible in Fig. 3, with rainfall and especially temperatures oscillating in intervals 3-4 weeks long. As a response, tree growth seems to be enhanced by higher temperatures and, to a smaller extent, by large amounts of rain. The February rainfall of $211 \mathrm{~mm}$ in 2002 was the highest ever recorded and well above the long-term average of $53.6 \mathrm{~mm}$. The data indicate that February rainfall affected tree growth positively at the end of the hot mid-summer period that had been responsible for a tree-growth breakdown.

The positive tree response was limited and after the second flood of rain growth decreased again. However, generally rainfall did not have any major impact on increment growth of the trees monitored. The correlation
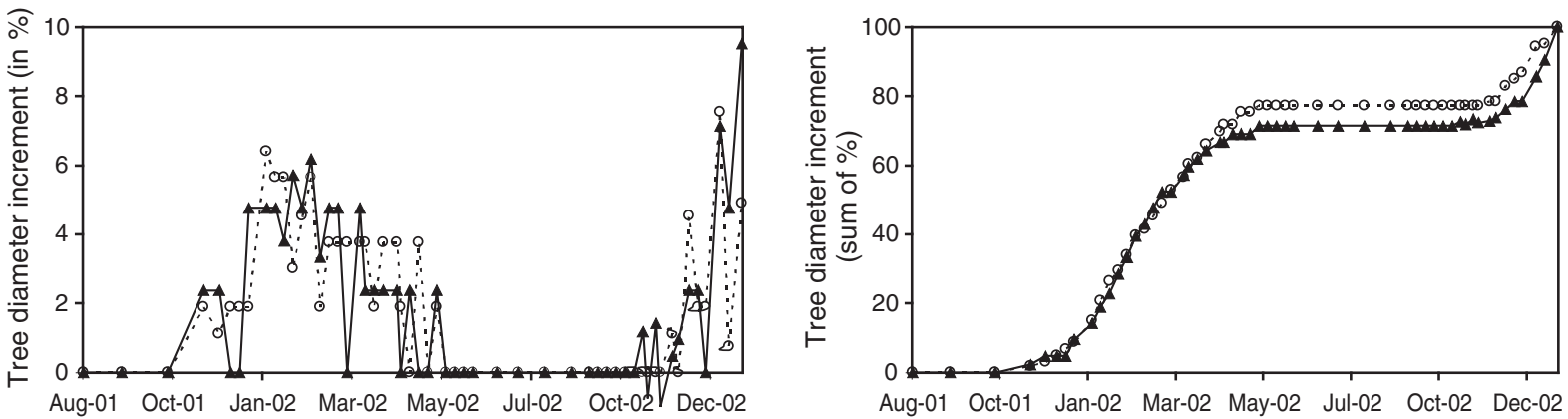

Fig. 2. Percentage diameter increases (left) and sum of percentage diameter increases (right) of Australian red cedars growing in the Australian National Botanic Garden, Canberra: Tree $1(\boldsymbol{\Delta})$ and Tree $2(\mathrm{O})$.
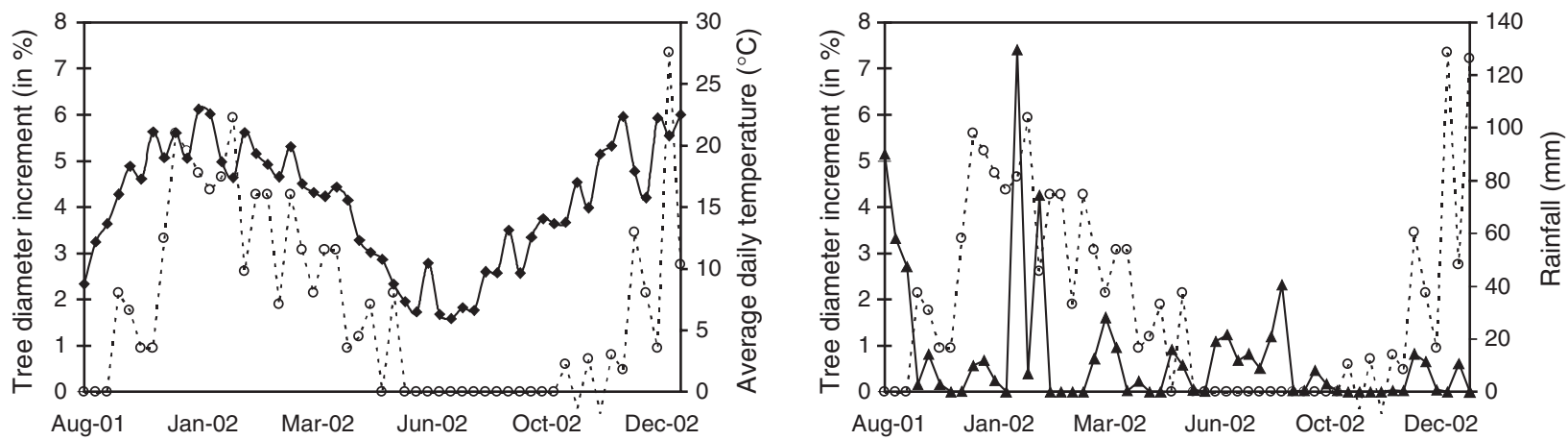

Fig. 3. Percentage diameter increases $(O)$ of Australian red cedars growing in the Australian National Botanic Garden, Canberra, in comparison with average daily temperature $(\bullet)$ (left) and sum of rainfall $(\boldsymbol{\Lambda})$ for measurement intervals (right) (Meteorological station: Canberra; Source: Bureau of Meteorology, Canberra 2002). 
Table 1. Correlation coefficients for diameter increments with rainfall and temperature data ${ }^{*} P<0.05,{ }^{* *} P<0.01$

\begin{tabular}{lcccc}
\hline & Daily rainfall & $\begin{array}{c}\text { Mean daily } \\
\text { temperature }\end{array}$ & $\begin{array}{c}\text { Max. daily } \\
\text { temperature }\end{array}$ & $\begin{array}{c}\text { Min. daily } \\
\text { temperature }\end{array}$ \\
\hline Canberra & & & & \\
Mean of Trees 1 \& 2 & 0.01 & $0.62^{* *}$ & $0.56^{* *}$ & $0.61^{* *}$ \\
Mean of Trees 1 \& 2 (Lag 1) & 0.18 & $0.75^{* *}$ & $0.74^{* *}$ & $0.71^{* *}$ \\
Mean of Trees 1 \& 2 (Lag 2) & 0.15 & $0.70^{* *}$ & $0.64^{* *}$ & $0.70^{* *}$ \\
Robertson & & & & \\
Mean of Trees 1-3 & 0.3 & $0.50^{* *}$ & 0.35 & $0.49^{* *}$ \\
Until 14 Jan. 2002 & -0.31 & $0.71^{* *}$ & 0.46 & $0.56^{*}$ \\
After 14 Jan. 2002 & $0.59^{*}$ & 0.4 & 0.29 & 0.43 \\
Mean of Trees 1-3 (Lag 1) & 0.02 & $0.67^{* *}$ & $0.78^{* *}$ & $0.51^{* *}$ \\
Mean of Trees 1-3 (Lag 2) & -0.29 & $0.58^{* *}$ & $0.51^{* *}$ & $0.46^{*}$ \\
Upper Kangaroo Valley & & & & \\
Mean of Trees 1-3 & 0.21 & 0.21 & 0.14 & 0.34 \\
Until Feb. 2002 & $0.82^{* *}$ & $-0.68^{*}$ & $-0.79^{* *}$ & 0.16 \\
After Feb. 2002 & 0.02 & -0.17 & -0.24 & -0.03 \\
\hline
\end{tabular}

coefficients listed in Table 1 indicate that temperature rather than rainfall was the limiting factor for growth of $T$. ciliata in Canberra. This is not surprising because Canberra is located outside of the species' natural distribution, with the climate in Canberra being too dry and cold. Because the trees are irrigated, rainfall is no longer a limiting factor; however, temperature is. In spring and autumn, temperatures have a positive effect on tree increments, but during the hottest months of December to January high temperatures can exert a negative impact on tree growth as implied by the simultaneous collapse of growth in mid-summer and the highest temperature peaks in Fig. 3. A lag effect in the correlation of one (Lag 1) and two (Lag 2) measurement periods and the growth values might reveal a delay in the trees' responses to the changing weather. In Table 1, the correlation between tree growth and Canberra rainfall is still not significant; however, the value for temperature is highly significant. The high temperature values from the previous 1-2 weeks seem to influence growth even more than the current temperature conditions.

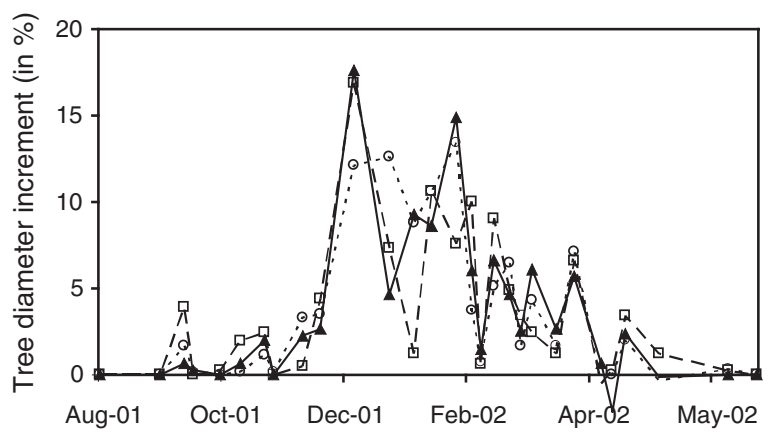

In Robertson, three trees were measured between August 2001 and June 2002 (Fig. 4). The trees became noticeably active at the beginning of October 2001 but grew slowly, with two breaks, until the start of the main growth flush. Between the beginning of December 2001 and the end of March 2002 the trees formed $90 \%$ of their overall growth increments. Two major peaks on 18 December and 2 February, with a low on 14 January, are discernible. In mid-February, growth almost came to a halt but resumed a week later on a lower level until the beginning of June 2002, and finally the trees fell into dormancy in mid-June. The diagrams for rainfall and temperature show that there is some correspondence between the two climate factors and growth of the three Robertson trees during the year (Fig. 5).

Table 1 lists the corresponding correlation coefficients, which propose that for the whole period temperature explains half of the variation, and rainfall almost a third. The Lag 1 and Lag 2 correlation values for rainfall are 0.02 and -0.29 , suggesting a delayed negative effect. The lagged correlation between temperature and growth data increases

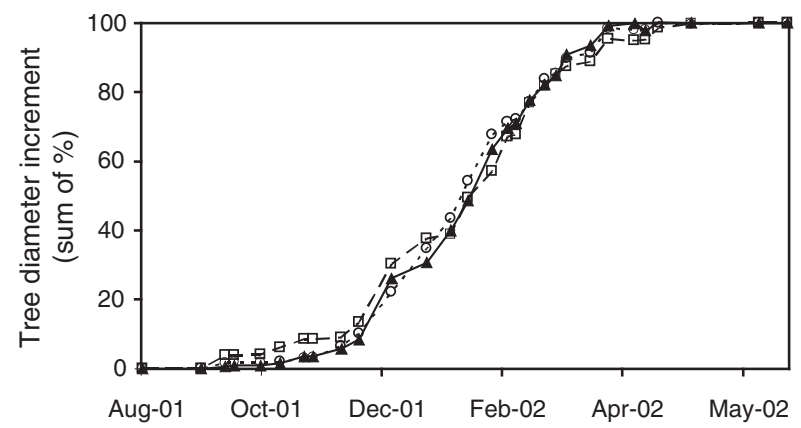

Fig. 4. Percentage diameter increases (left) and sum of percentage diameter increases (right) of Australian red cedars growing in Robertson: Tree $1(\mathbf{\Delta})$, Tree $2(\bigcirc)$ and Tree $3(\square)$. 

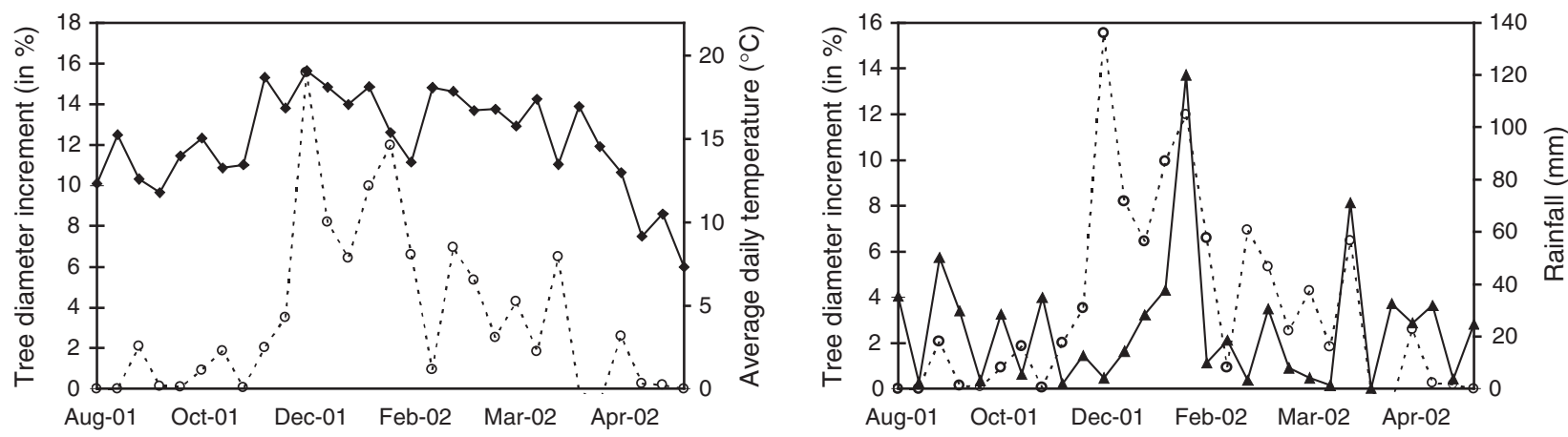

Fig. 5. Percentage diameter increases $(O)$ of Australian red cedars (average 1-3) growing in Robertson, in comparison with average daily temperature $(\bullet)$ (left) and sum of rainfall for measurement intervals $(\boldsymbol{\Delta})$ (right) (Meteorological station: Robertson; Source: Bureau of Meteorology, Canberra 2002).

significantly, especially on the first lag. This implies that higher temperatures of the previous measurement interval resulted in larger increments during the current growth interval (Table 1). Robertson is situated at the limit of the natural range of $T$. ciliata and because of its position on the Southern Tablelands, temperature conditions are probably not favourable, especially at the beginning and end of the season.

Table 1 also shows that the correlation patterns for Robertson split into two periods: the periods before and after 14 January. This point in time was chosen because the visual examination of Figs 4 and 5 suggests that from then on a change in correspondence between the tree growth and the two climate factors exists. The correlation for rainfall is negative for the first period and positive for the second, indicating that the contents of the pre-season soil moisture were already at an optimum level and additional rainfall hindered growth, rather than supporting it. After 14 January, soil moisture became limiting and rainfall had a direct positive effect on tree growth. In contrast, average temperature values were extremely limiting during the first period but less so after 14 January.

Three trees in UKV were measured approximately on a monthly basis from September 2001 to February 2002, and then again from May to July 2002. The trees became active in mid-September 2001, after a new flush of leaves occurred at the beginning of September 2001. The trees produced almost $20 \%$ of their annual growth increment by the beginning of October (Fig. 6). From November to December the growth slowed down markedly and reached a second peak by the end of January 2002. In February, tree growth decreased until May, when it rose again, and finally slowed down radically towards the beginning of July 2002, the end of the growing season. During the two major growth phases, between September and November 2001 and January 2002 , roughly $65 \%$ of the annual growth increment was accomplished.

The climate and tree growth-increment data are illustrated in Fig. 7, with rainfall data from Kangaroo Valley and temperature values from Bowral, the nearest station on the tablelands recording temperature. The relationship between temperature and tree growth is largely reciprocal. When temperatures are high tree growth slows down, and vice versa. The rainfall and tree-growth values develop in parallel but this positive correlation ends in February 2002. In December 2001, UKV experienced a dry period during which tree growth slowed down. In contrast, in February 2002 the site received a large amount of rain for a relatively short period, which saw tree growth decelerating again.

The correlation coefficients between tree growth and the climate data are listed in Table 1. The coefficients for
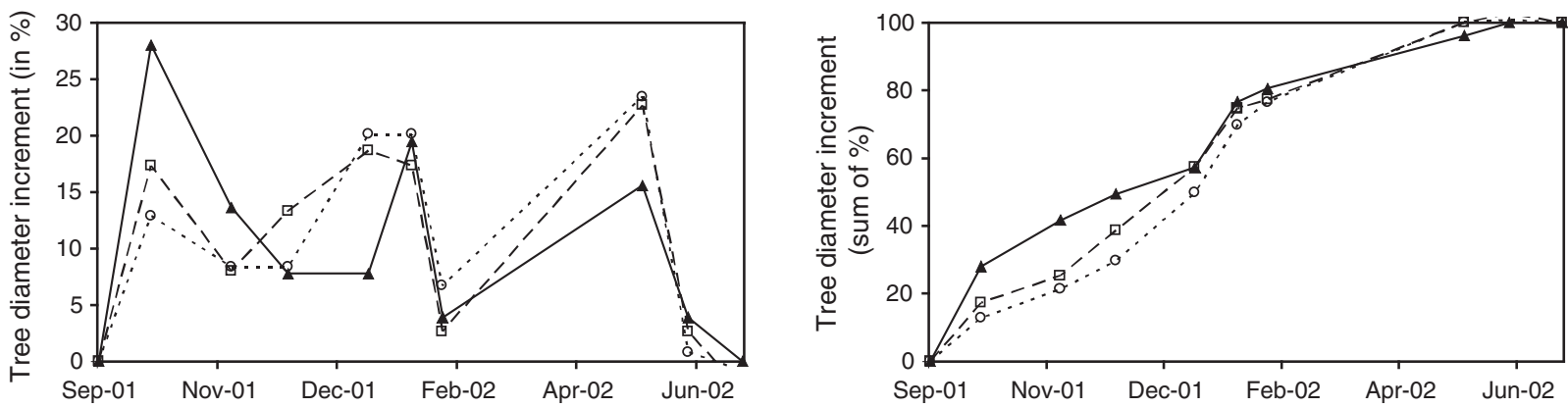

Fig. 6. Percentage diameter increases (left) and sum of percentage diameter increases (right) of Australian red cedars growing in Upper Kangaroo Valley: Tree $1(\boldsymbol{\Delta})$, Tree $2(\bigcirc)$ and Tree $3(\square)$. 

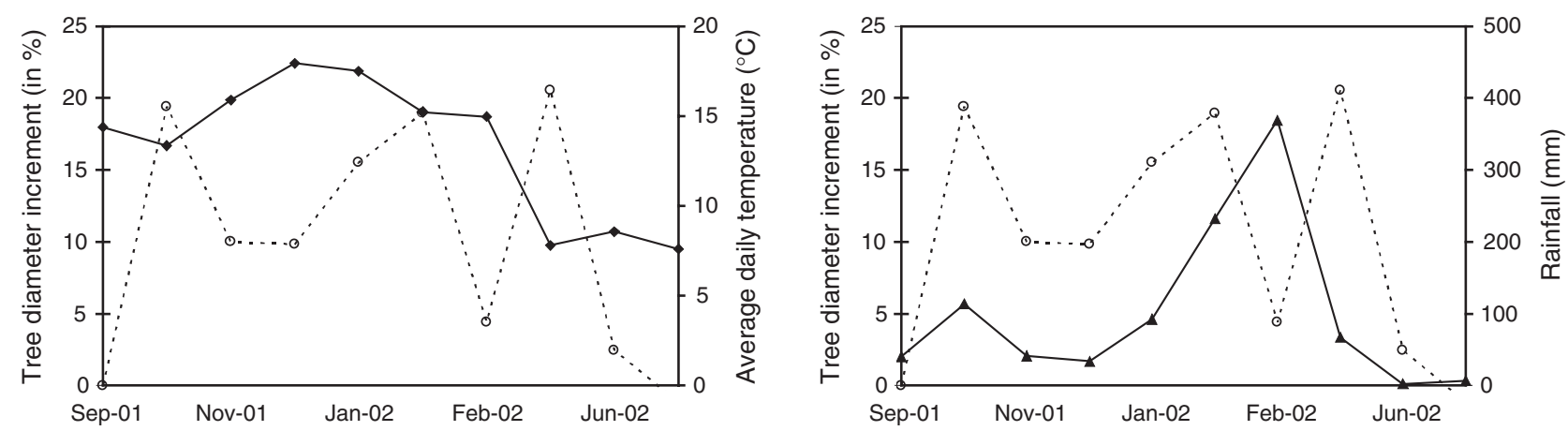

Fig. 7. Percentage diameter increases $(\mathrm{O})$ of Australian red cedars growing in Upper Kangaroo Valley, in comparison with average daily temperature $(\bullet)$ (left) and sum of rainfall for measurement intervals ( $\mathbf{\Delta}$ ) (right) (Meteorological stations: Kangaroo Valley for rainfall and Bowral for temperature; Source: Bureau of Meteorology, Canberra 2002).

rainfall and temperature are on an equally low level for the whole period. Because February was such an unusually wet month $(292 \mathrm{~mm})$, the correlation coefficients were calculated separately for the periods up to February and after February 2002. The coefficients propose that rainfall exerted a strong positive effect and temperature a negative effect on the tree growth until February 2002. Under normal conditions, i.e. rainfall and temperature staying within certain limits, tree growth in UKV increases with higher rainfall and lower temperature. The site chronology from UKV presented below supports this hypothesis, with all monthly temperature data except for September exhibiting a negative correlation with the annual tree-ring data. The rainfall data display only a weak relationship with the tree-ring data, which might be explained by the interference of unusually high rainfall events such as the one in February 2002. If too many of those events occurred during the period of observation, the correlation coefficients between rainfall and annual tree rings would also be affected.

\section{Tree-ring data}

The repetitive sampling of a single tree in UKV helped to clarify that $T$. ciliata forms initial parenchyma bands. Figure 8 shows three samples, taken in winter 2000 (dormant), spring 2000 (early season) and summer 2001 (growth period). The sequence illustrates that the Australian red cedar has tree rings comprising large vessel elements embedded in initial tangential parenchyma cells in the earlywood and vessels of decreasing size in the progression from early- to latewood (Carlquist 1988). In spring, with leaves already unfolding, a definite sign for this year's season, the cambium had not yet produced any parenchyma (indicated by white arrows in Fig. 8). The zone of initial parenchyma is visible only in the summer sample after most of the growth ring had been formed. Therefore, in the current study the annual tree rings will be measured from the earliest parenchyma cells to the last row of latewood cells.

We now assess the UKV site chronology for its quality and usefulness for dendroclimatological studies. The raw data are shown, with the sample from the oldest tree covering the first half of the period (Fig. 9). Both the old tree and the younger trees exhibit a growth trend, large annual variations and some common variance pronounced graphically by the black areas.

In Table 2, typical tree-ring statistics are summarised, where in the first row the mean, minimum and maximum annual increments are indicators for the overall growth of the stand and the standard deviation is a measure of scatter of the data from their mean expressed in the original

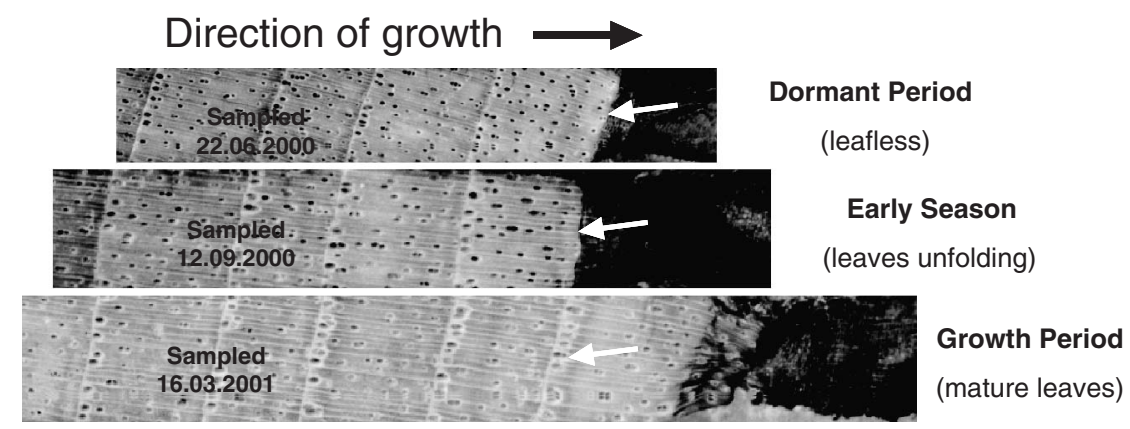

Fig. 8. Samples from the same tree taken in winter (top), spring (middle) and summer (bottom). 


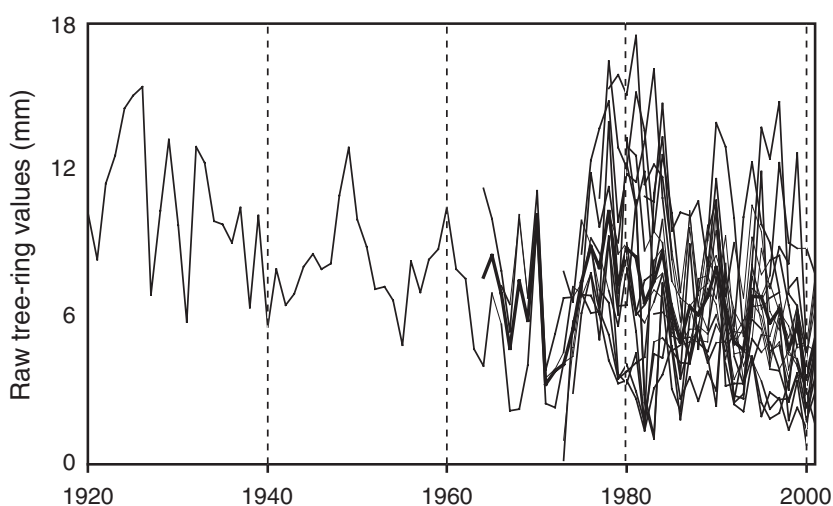

Fig. 9. Raw tree-ring values from 18 samples, with average (bold line).

Table 2. Summary statistics for Upper Kangaroo Valley site index

\begin{tabular}{ll}
\hline Mean (min./max.) annual increment $(\mathrm{mm})$ & $6.76(0.15 / 17.49)$ \\
Standard deviation $(\mathrm{mm})$ & 3.17 \\
Coefficient of variation before and & $1001.8,9.29$ \\
$\quad$ after standardisation $(\%)$ & 0.33 \\
Mean sensitivity & $0.466,0.021$ \\
$\quad$ Mean autocorrelation before and after & \\
$\quad$ standardisation & 1970 \\
1st-year expressed population signal > 0.85 & 0.449 \\
Series intercorrelation &
\end{tabular}

unit of millimetres. The young, fast-growing trees at UKV have a large mean annual growth increment $(6.76 \mathrm{~mm})$, and the minimum and maximum values of the annual growth increments exhibit a wide range from $0.15 \mathrm{~mm}$ to more than $17 \mathrm{~mm}$, typical for young specimens, confirmed by the standard deviation of the raw values $(3.17 \mathrm{~mm})$. Since the data have a normal distribution, two-thirds of the data lie within a distance of this standard deviation on each side of the mean $(6.76 \mathrm{~mm})$. The coefficients of variation before and after the detrending expressed as percentages of the mean demonstrate the successfulness of the standardisation, which reduced the variation to approximately $10 \%$. The mean sensitivity (0.33) and the series intercorrelation (0.45) suggest good potential for dendroclimatic research. The value for the mean autocorrelation decreased after the standardisation, indicating that the low-frequency variance originating from non-randomness other than climate had been filtered out by the cubic smoothing spline.

Since the early parts of the chronology had a small sample size, all series were cut off at 1970 when the values for the EPS drop below 0.85 , as noted in Table 2. Only the data of the remaining years 1970-2001 will enter the following climate-response analysis.

The diagrams in Fig. 10 illustrate how the standardisation has been successful in removing the long-term trend of decreasing growth, smoothing outliers and enhancing the common variance visible in the bottom diagram. The series
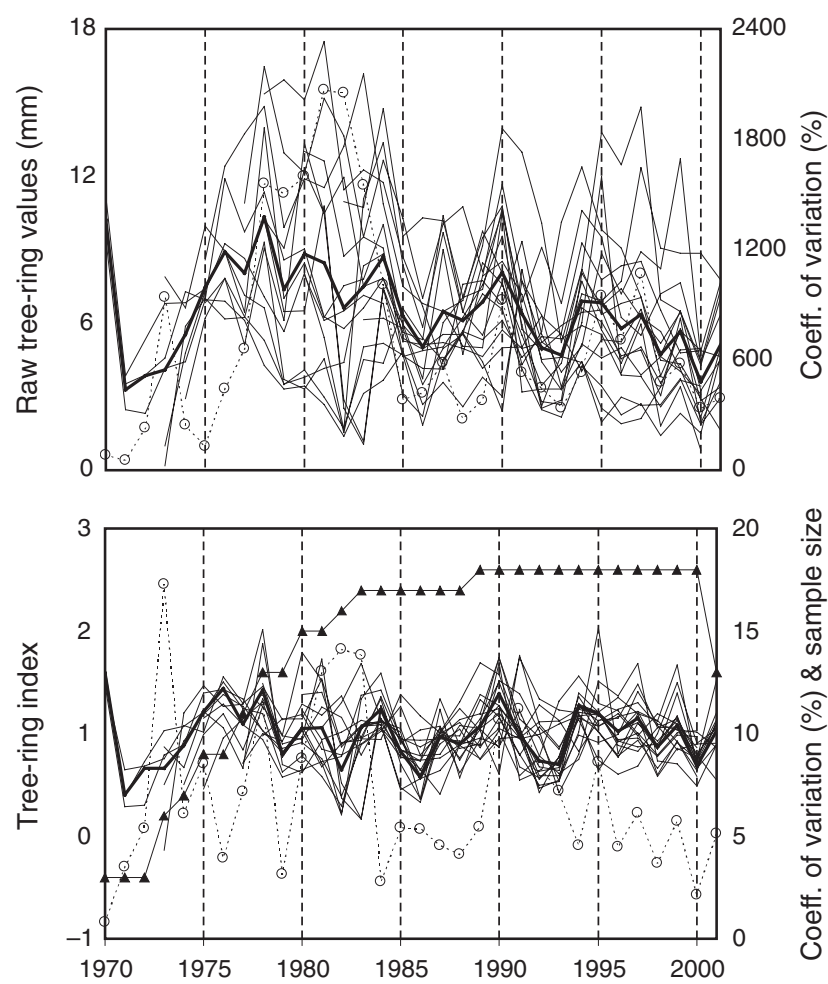

Fig. 10. Raw tree-ring (top) and tree-ring index values (bottom), with averages (bold line), sample size $(\boldsymbol{\Lambda})$ and coefficient of variation $(O)$ from Upper Kangaroo Valley.

consists mainly of young trees and shows a large spread of the individual raw values around the mean, but after standardisation the index values are clustered closer to the overall mean in the bottom diagram. Periods of below-average growth are visible for the years 1971-1973 and 1991-1993, which partly correspond with major El Niño drought years in the early 1970s, 1980s and 1990s. Years of aboveaverage growth are shown for the years 1976, 1978, 1990, 1994 and 1995.

In a next step, the mean tree-ring index (bold black graph in the bottom diagram of Fig. 10) was correlated with various climate parameters. The results of each correlation analysis are plotted in three histograms which are subdivided into three parts by vertical dashed lines (Fig. 11). The left side of each diagram starts with the period January-August of the previous year, the middle part covers the current growth year from September to August, and on the right side the small letters stand for the annual value (a) and the averages for the periods September-November (b), December-February (c), March-May (d) and June-August (e) of the current season. In each diagram, the $95 \%$ confidence intervals are indicated by the horizontal dashed lines.

The data for precipitation from March to August in the previous year and the annual tree growth are correlated positively, although below the significance value. Subsequently, the correlation declines and turns negative 

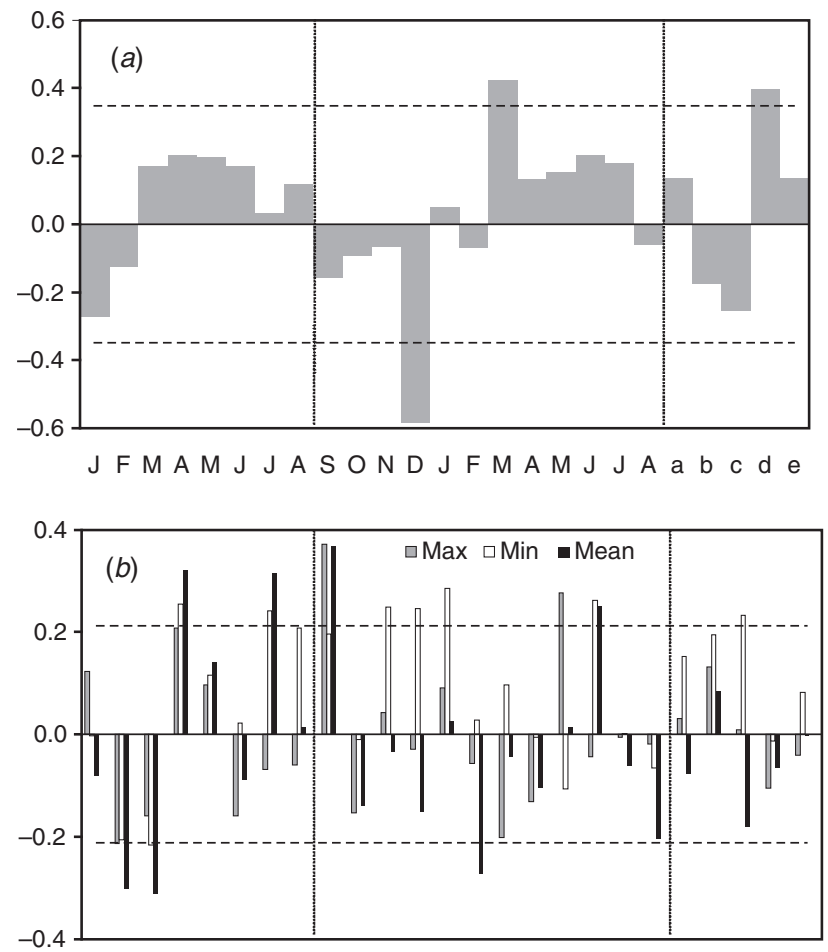

$J F M A M J J A S O N D J F M A M J J A a b a d e$

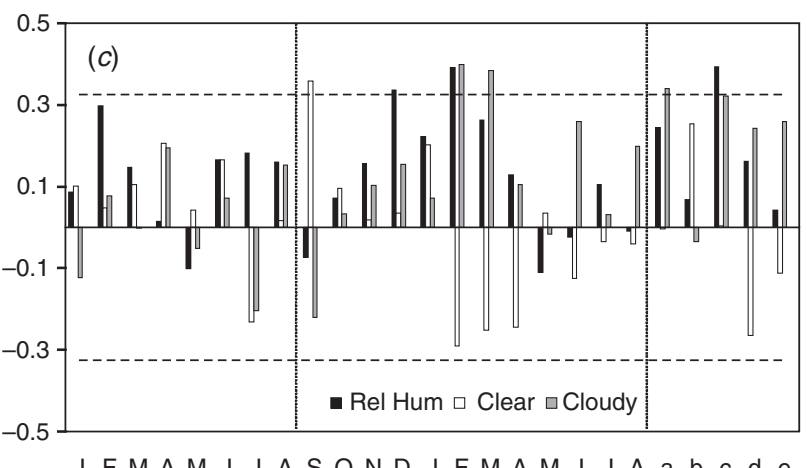

Fig. 11. Climate-response plots for Upper Kangaroo Valley (UKV) site index with meteorological data: monthly coefficients of correlation between the UKV site index and $(a)$ monthly and seasonal values of Kangaroo Valley precipitation, $(b)$ maximum, minimum and mean Bowral temperature and $(c)$ relative humidity and the number of clear and cloudy days at Bowral (for further explanation see text).

during the first half of the current growing period, becoming positive again between March and July. However, the values rise above the significance value in December (negative value) and March (positive value) only (Fig. 11a).

The results for the temperature values from the dendrometer-band study are partly confirmed by Fig. $11 b$. The minimum temperatures exert a significant positive effect on tree growth during the hottest period of the year between November and March, whereas the mean and maximum temperatures show weak correlations with tree growth. The minimum and mean temperatures of the deciduous period in July and August of the previous growing period and the tree growth are correlated positively.

The level of correlation between relative humidity and the tree growth increases from October to a peak in February, decreasing again to a low point in May (Fig. 11c). This suggests that trees in UKV grow faster when relative humidity levels are high. However, in September the situation is reversed, i.e. a positive correlation between tree growth and the number of clear days and a negative correlation between tree growth and both relative humidity and the number of cloudy days indicate that trees grow faster when sunny, dry and warm weather conditions prevail at the beginning of the growing period. The correlation changes in February-April, which implies that during this season trees suffer from dry, sunny and hot conditions. During the months October-January, the correlation patterns are inconsistent because numbers of clear and cloudy days both correlate positively with tree growth. In contrast, the correlation for February-April suggests that increment growth is supported by more humid and cloudy conditions. No obvious correlation patterns are apparent for the months of the previous season in Fig. 11c.

\section{Discussion}

The current study has confirmed that the Australian red cedar forms distinct growth rings that range from ring-porous to semi-ring-porous, with initial parenchyma and large earlywood vessels, followed by latewood with vessels decreasing in size. The species is fully deciduous throughout its natural range (Boland 2000) and hence dormancy during the cooler and dryer winter months could be expected. The dendrometer-band data showed that all Australian red cedars monitored entered a dormant period lasting between 4.5 months in Canberra and 3-3.5 months in Robertson and UKV. Although Robertson is located at a higher altitude, and site conditions, as a result, should restrict growth more distinctly than in UKV, the dormancy in UKV lasted longer, indicating that tree growth is more limited in UKV than in Robertson. However, since the trees from Robertson were younger than those in UKV, the results cannot simply be compared. Similar studies conducted in the tropics (Coster 1928; Chowdhury 1964; Tomlinson and Longman 1981; Fahn et al. 1981) revealed that younger trees showed less distinct periodic growth patterns than did older trees. The younger trees continuously developed new shoots, thus constantly keeping up high levels of hormones promoting growth. This, on the other hand, inhibited the cambium from going into dormancy for longer than in mature trees. The younger tree ages in Robertson might be the reason for the shorter dormancy at this location than in UKV.

Growth of $T$. ciliata was found to be related to either temperature or precipitation, depending on the geographical location. The tree-growth increments in Canberra were 
correlated positively with temperature, whereas the growth in Robertson and UKV showed more coherence with precipitation. The ANBG is located outside the natural distribution of the species and the continental climate often is extensively hot in summer and cold in winter for longer periods. This explains the stronger relationship between the growth of $T$. ciliata and temperature in Canberra than that at the coastal sites where tree growth was mainly influenced by the more maritime climate. Near the coast, temperatures are distributed evenly throughout the year and precipitation becomes the major factor limiting tree growth. The examination of the diagrams including temperatures and diameter growth (Figs 3, 5 and 7) at the three sites showed that temperatures of approximately $10^{\circ} \mathrm{C}$ or below occur when the trees are dormant. However, whether the trees entered dormancy as a result of photoperiodic, temperature or humidity changes cannot be answered here.

In Canberra and Robertson, tree growth exhibited a distinct lagged correlation with the temperature of the previous interval, which indicates a delayed growth reaction. The correlation between growth and rainfall data, when divided into two time periods, illustrated that in Robertson trees grow faster when weather conditions are hot and dry in the early season but more humid and warm during the second half of the growing period. The limit of the natural range of $T$. ciliata growing in Robertson is probably due to too humid and cool conditions, especially during the first half of the season. The results in UKV, also divided into two intervals, suggest that under normal weather conditions without extreme rainfall events trees grow faster when above-average rainfall and below-average temperatures occur. Additionally, it was found that rainfall can limit growth in two ways, both through very dry and very wet conditions, which has also been discovered for $T$. ciliata in India (Bhattacharyya et al. 1992). The authors found that narrow tree rings in their site chronology could be explained by both above- and below-average monthly rainfall. They came to the conclusion that the tree rings of $T$. ciliata could be used to reconstruct both drought and flooding events.

For the first time, it was possible to cross-date samples taken from T. ciliata in Australia, opening the way for further dendroclimatological investigations. After standardisation, which filtered out growth trends and other non-common variance, the quality of the site chronology was sufficient enough to try a climate-response plot correlation analysis. The correlation with precipitation at UKV suggests that fast growth of the Australian red cedar occurs largely under drier conditions during the first half of the growing period and under wetter conditions during the second part of the growing period. The positive correlation patterns between growth and monthly rainfall between April and July of both the previous and the current year imply that the soil profile is filled up with water during this time; at the beginning of the vegetation period trees seem to use this reservoir first, without much further demand for more precipitation, indicated by the slightly negative correlation with monthly rainfall during the first half of the year. In September, high temperatures support growth at the beginning of the vegetation period. This is also the only month in which there is significant positive correlation between tree growth and the number of clear days. It seems that the trees prefer dry and warm weather in spring. The rising positive correlation between growth and both relative humidity and the number of cloudy days later in the year suggests that once the soil water reservoirs are exhausted, the trees become more reliant on the current precipitation and are stressed more by high maximum and mean temperatures.

The annual rainfall displays only a weak positive relationship with the tree-ring data, which might be explained by the interference of unusually high rainfall events comparable with February 2002. If too many of such events occurred during the observed period, the correlation between rainfall and annual tree rings would be affected negatively. The question of what is the upper limit for the rainfall values to start exerting a negative effect on tree growth cannot be answered yet because of a lack of data. Such data could be generated by long-term dendrometer-band studies lasting for more than one season.

The correlation coefficient between growth and December precipitation almost reaches the highly significant value of 0.6. In comparison to the other climate data available for this site, this value is difficult to explain ecologically. The climate diagram in Fig. 1 illustrates how evenly distributed the long-term rainfall is throughout the year. Simultaneously, in December the temperature values reach a peak, opening the gap between rainfall and temperature data to a maximum, which would suggest that probably heat stress and/or water availability limit tree growth most. Therefore, in December it might be expected that tree growth would profit from lower temperatures and higher humidity levels, i.e. a positive correlation value between growth and precipitation would result. However, the highly significant negative correlation in December suggests that trees grow better under less humid conditions. One possible explanation for the discrepancy might be that the long-term mean values in Fig. 1 hide many extreme rainfall events especially in December, which might have negative effects on tree growth during this time. Support for this theory comes from the dendrometer analysis. The dendrometer data also showed a general positive relationship between rainfall and tree growth until the torrential rains hit the site in February 2002, which resulted in a sharp decrease of tree growth. Subsequently, the coefficient of correlation turned negative during this period. Once the rain stopped, tree growth increased again and remained high until the end of the growing season, profiting from the humidity stored in the soil. A similar process might be responsible for the negative correlation between precipitation and 
tree growth in December. Further long-term dendrograph or dendrometer-band studies are needed to clarify such processes.

Generally, the climate data exhibit only a limited correlation with tree growth in UKV and possible explanations are false rings not detected in the analysis. False rings can occur in $T$. ciliata but only in younger trees or probably in adult specimens under very extreme conditions such as total defoliation during a direct cyclone hit or a very extreme drought followed by a fire entering the rainforest, as was suggested by Herwitz et al. (1998). Further statistical noise might have been incorporated through possible shootborer attacks, which have been found to occur especially in young trees growing in open and light conditions (Mo et al. 1997a, 1997b). Since the UKV forest stand was a more open regenerating rainforest, better cross-dating results are expected from mature closed-canopy rainforest stands, if the borer infestations were a reason for the noise within the series.

Although this preliminary analysis was conducted only on young material, both dendrometer-band and tree-ring studies revealed that $T$. ciliata has a good potential for further dendroclimatological studies. The species is deciduous and dormant for longer intervals and it grows naturally at several sites along the eastern coast of Australia, with potential sample material from diverse forests. Except for the statistical peculiarity of the highly negative December correlation, the UKV site has the potential to reconstruct rainfall of the second half of the season, especially March, and also early season temperatures, in particular September values. However, more sampling is necessary to increase the reliability of the dataset and also to increase the length of the time series. At UKV, the species has reached the southernmost limit of its distribution, and temperatures probably delay or inhibit growth more distinctly than at locations further north where a more distinct correlation with rainfall might be expected.

\section{Acknowledgments}

We thank Theresa Heighes and Hugh and Adele Waring for access to the trees on their properties and for conducting the dendrometer-band measurements. We are also grateful for the support from John Nightingale, Australian National Botanic Gardens. Two anonymous reviewers provided helpful comments on previous versions of the manuscript. Ingo Heinrich received a $\mathrm{PhD}$ scholarship from the Australian National University, the CRC for Greenhouse Accounting and the German Academic Exchange Service (DAAD).

\section{References}

Allen KJ (2002) The temperature response in the ring widths of Phyllocladus aspleniifolius (celery-top pine) along an altitudinal gradient in the Warra LTER area, Tasmania. Australian Geographical Studies 40, 287-299. doi: 10.1111/1467-8470.00181
Allen KJ, Cook ER, Francey RJ, Michael K (2001) The climatic response of Phyllocladus aspleniifolius (Labill.) Hook. fin Tasmania. Journal of Biogeography 28, 305-316. doi: 10.1046/J.1365-2699.2001.00546.X

Ash J (1983) Growth rings in Agathis robusta and Araucaria cunninghamii from tropical Australia. Australian Journal of Botany 31, 269-275.

Bahadur KN (1988) 'Monograph on the genus Toona (Meliaceae).' (Bishen Singh Mahendra Pal Singh: Dehra Dun, India)

Banks JCG (1982) The use of dendrochronology in the interpretation of the dynamics of the snow gum forest. PhD Thesis, Australian National University, Department of Forestry, Canberra.

Berlage HP (1931) Over het verband tusschen de dikte der jaaringen van djatiboomen (Tectona grandis L.f.) en den regenval op Java. Tectona 24, 939-953.

Bhattacharyya A, Yadav RR, Borgaonkar HP, Pant GB (1992) Growthring analysis of Indian tropical trees: dendroclimatic potential. Current Science 62, 736-741.

Boland DJ (2000) 'Toona ciliata M.Roemer.' (Electronic Forestry Compendium Global Module, CAB International: Wallingford, UK)

Boland DJ, Brooker MIH, Chippendale GM, Hall N, Hyland BPM, Johnston RD, Kleinig DA, Turner JD (2002) 'Forest trees of Australia.' (CSIRO Publishing: Melbourne)

Bormann FH, Kozlowski TT (1962) Measurements of tree growth with dial gage dendrometers and vernier tree ring bands. Ecology 43, 289-294.

Bowers NA (1964) New method of surfacing wood specimens for study. Tree-Ring Bulletin 26, 2-5.

Bowler JM, Johnston H, Olley JM, Prescott JR, Roberts RG, Shawcross W, Spooner NA (2003) New ages for human occupation and climatic change at Lake Mungo, Australia. Nature 421, 837-840. doi: 10.1038/NATURE01383

Bowman DMJS, Cook GD (2002) Can stable carbon isotopes $\left(\delta^{13} \mathrm{C}\right)$ in soil carbon be used to describe the dynamics of Eucalyptus savannarainforest boundaries in the Australian monsoon tropics? Austral Ecology 27, 94-102. doi: 10.1046/J.1442-9993.2002.01158.X

Briffa KR, Jones PD (1990) Basic chronology statistics and assessment. In 'Methods in dendrochronology'. (Eds ER Cook, LA Kairiukstis) pp. 137-152. (International Institute for Applied System Analysis: Dordrecht, The Netherlands)

Buckley BM, Barbetti M, Watanasak M, D'Arrigo DR, Boonchirdchoo S, Sarutanon S (1995) Dendrochronological investigations in Thailand. IAWA Journal 16, 393-409.

Carlquist SJ (1988) 'Comparative wood anatomy. Systematic, ecological and evolutionary aspects of dicotyledon wood.' (Springer Verlag: Berlin)

Chowdhury KA (1940) The formation of growth rings in Indian trees. Indian Forest Records-Part III. New Series. Utilisation 2, $59-75$.

Chowdhury KA (1964) Growth-rings in tropical trees and taxononmy. The Journal of The Indian Botanical Society 43, 334-343.

Cook ER, Holmes RL (1986) 'Users manual for program ARSTAN.' (Laboratory of Tree-Ring Research, University of Arizona: Tucson, AZ)

Cook ER, Kairiukstis LA (1990) 'Methods of dendrochronology.' (International Institute for Applied System Analysis: Dordrecht, The Netherlands)

Cook ER, Peters K (1981) The smoothing spline: a new approach to standardizing forest interior tree-ring width series for dendroclimatic studies. Tree-Ring Bulletin 41, 45-53.

Cook ER, Bird T, Peterson M, Barbetti M, Buckley B, D'Arrigo R, Francey R, Tans P (1991) Climatic change in Tasmania inferred from a 1089-year tree-ring chronology of huon pine. Science $\mathbf{2 5 3}$, 1266-1268. 
Cook ER, Bird T, Peterson M, Barbetti M, Buckley B, D'Arrigo R, Francey R (1992) Climatic change over the last millennium in Tasmania reconstructed from tree-rings. The Holocene $\mathbf{2}$, 205-217.

Coster C (1928) Zur Anatomie und Physiologie der Zuwachszonen und Jahresringbildung in den Tropen. Annales du Jardin Botanique de Buitenzorg 38, 1-114.

D'Costa DM, Kershaw AP (1995) A Late Pleistocene and Holocene pollen record from Lake Terang, Western Plains of Victoria, Australia. Palaeogeography, Palaeoclimatology, Palaeoecology 113, 57-67. doi: 10.1016/0031-0182(95)00062-Q

De Deckker P (2001) Late Quaternary cyclic aridity in tropical Australia. Palaeogeography, Palaeoclimatology, Palaeoecology 170, 1-9. doi: 10.1016/S0031-0182(01)00233-4

Edmonds JM (1995) Toona. In 'Meliaceae, Flora Malesiana, Series Spermatophyta 12'. (Eds DJ Mabberley, CM Pannell, AM Sing) pp. 358-371. (Foundation Flora Malesiana by the Rijksherbarium/Hortus Botanicus: Leiden, The Netherlands)

Fahn A, Burley J, Longman KA, Mariaux A, Tomlinson PB (1981) Possible contributions of wood anatomy to the determination of the age of tropical trees. In 'Age and growth rate of tropical trees: new directions for research'. (Eds FH Bormann, G Berlyn) pp. 31-54. Proceedings of the workshop on age and growth rate determination for tropical trees, New Haven, Yale University.

Floyd AG (1979) NSW rainforest trees. Part VIII. Forestry Commission of NSW, Research note no. 38, Sydney.

Fritts HC (1976) 'Tree rings and climate.' (Blackburn Press: Caldwell, NJ)

Herwitz SR, Slye RE, Turton SM (1998) Redefining the ecological niche of a tropical rain forest canopy tree species using airborne imagery: long-term crown dynamics of Toona ciliata. Journal of Tropical Ecology 14, 683-703. doi: 10.1017/S0266467498000480

Holmes RL (1994) 'Dendrochronolgy program manual.' (Laboratory of Tree-ring Research: Tucson, AZ)

Hopkins MS, Graham AW, Hewett R (1990) Evidence of late Pleistocene fires and eucalypt forest from a North Queensland humid tropical rainforest site. Australian Journal of Ecology 15, 345-347.

Hopkins MS, Head J, Ash JE, Hewett RK, Graham AW (1996) Evidence of a Holocene and continuing recent expansion of lowland rain forest in humid, tropical North Queensland. Journal of Biogeography 23, 737-745.

Jacoby GC, D'Arrigo RD (1990) Teak (Tectona grandis L.f.), a tropical species of large scale dendroclimatic potential. Dendrochronologia 8, 83-98.

Kaennel M, Schweingruber FH (1995) 'Multilingual glossary of dendrochronology. Terms and definitions in English, German, French, Spanish, Italian, Portuguese, and Russian.' (Swiss Federal Institute for Forest, Snow and Landscape Research, and Paul Haupt: Bern, Switzerland)

Kershaw AP (1978) Record of last interglacial-glacial cycle from northeastern Queensland. Nature 272, 159-161.

Kozlowski TT (1962) Photosynthesis, climate, and tree growth. In 'Tree growth'. (Ed. TT Kozlowski) pp. 149-164. (New York)

Mo J, Tanton MT, Bygrave FL (1997a) Temporal and inter-tree variations of attack by Hypsipyla robusta Moore (Lepidoptera: Pyralidae) in Australian red cedar (Toona australis (F.Muell.) Harmes). Forest Ecology and Management 96, 139-146. doi: 10.1016/S0378-1127(97)00017-0

Mo J, Tanton MT, Bygrave FL (1997b) Within-tree distribution of attack by Hypsipyla robusta Moore (Lepidoptera: Pyralidae) in Australian red cedar (Toona australis (F.Muell.) Harmes). Forest Ecology and Management 96, 147-154. doi: 10.1016/S0378-1127(97)00018-2
Mucha SB (1979) Estimation of tree ages from growth rings of eucalypts in northern Australia. Australian Forestry 42, $13-16$.

Murphy JO (1994) A dendroclimatic study of teak from East Java. Proceedings of the Koninklijke Nederlandse Akademie van Wetenschappen 97, 183-199.

Ogden J (1981) Dendrochronological studies and the determination of tree ages in the Australian tropics. Journal of Biogeography $\mathbf{8}$, 405-420.

Pilcher JR (1990) Sample preparation, cross-dating, and measurement. In 'Methods in dendrochronology'. (Eds ER Cook, LA Kairiukstis) pp. 40-51. (International Institute for Applied System Analysis: Dordrecht, The Netherlands)

Rayner ME (1992) Application of dendrochronology, stem analysis and inventory data in the estimation of tree and stand ages in Karri forest. Department of Conservation and Land Management, Technical Report No. 27, Perth.

Schweingruber FH (1983) 'Der Jahrring. Standort, Methodik, Zeit und Klima in der Dendrochronologie.' (Swiss Federal Institute for Forest, Snow and Landscape Research, and Paul Haupt: Bern, Switzerland)

Schweingruber FH (1992) Annual growth rings and growth zones in woody plants in Southern Australia. IAWA Bulletin 13, $359-379$.

Schweingruber FH, Kairiukstis L, Shiyatov S (1990) Sample selection. In 'Methods in dendrochronology'. (Eds ER Cook, LA Kairiukstis) pp. 23-35. (International Institute for Applied System Analysis: Dordrecht, The Netherlands)

Stahle DW (1999) Useful strategies for the development of tropical tree-ring chronologies. IAWA Bulletin 20, 249-253.

Stahle DW, D'Arrigo RD, Krusic PJ, Cleaveland MK, Cook ER, Allan RJ, Cole JE, Dunbar RB, Therrell MD, Gay DA, Moore MD, Stokes MA, Burns BT, Villanueva-Diaz J, Thompson LG (1998) Experimental dendroclimatic reconstruction of the southern oscillation. Bulletin of the American Meteorological Society 79, 2137-2152. doi: 10.1175/1520-0477(1998)079<2137:EDROTS > 2.0.CO;2

Stocker GC (1971) The age of charcoal from old jungle fowl nests and vegetation change on Melville Island. Search 2, 28-30.

Stokes MA, Smiley TL (1968) 'An introduction to tree ring dating.' (University of Chicago Press: Chicago, IL)

Tomlinson PB, Longman KA (1981) Growth phenology of tropical trees in relation to cambial activity. In 'Age and growth rate of tropical trees: new directions for research'. (Eds FH Bormann, G Berlyn) pp. 7-19. Proceedings of the workshop on age and growth rate determination for tropical trees, New Haven, Yale University.

Vader J (1987) 'Red gold: the tree that built a nation.' (New Holland Publishers: Sydney)

Wigley TML, Briffa KR, Jones PD (1984) On the average of correlated time series, with applications in dendroclimatology and hydrometeorology. Journal of Climate and Applied Meteorology 23, 201-213. doi: $10.1175 / 1520-0450(1984) 023<0201$ :OTAVOC $>2.0$. CO; 2

WinDENDRO (2003) 'WinDENDRO manual.' (Régent Instuments Inc.: Québec, Canada)

Worbes M (1990) Site and sample collection in tropical forests. In 'Methods in dendrochronology'. (Eds ER Cook, LA Kairiukstis) pp. 35-40. (International Institute for Applied System Analysis: Dordrecht, The Netherlands)

Manuscript received 3 March 2004, accepted 17 August 2004 